\title{
WAYS OF PRESENTING ENVIRONMENTAL ELEMENTS IN OLD CARTOGRAPHIC RECORDS AND THEIR RELIABILITY
}

\author{
Alfred KANIECKI \\ Adam Mickiewicz University, Institute of Physical Geography and Environmental Planning, Poznań, Poland
}

Manuscript received: November 15, 2010

Revised version: February 27, 2011

KANIECKI A., 2011. Ways of presenting environmental elements in old cartographic records and their reliability. Quaestiones Geographicae 30(1), Bogucki Wydawnictwo Naukowe, Poznań, pp. 31-45, 6 Figs. ISBN 978-83-6266239-5. ISSN 0137-477X. DOI 10.2478/v10117-011-0003-3.

ABSTRACT. This article seeks to assess the reliability of the hydrographic type of environmental features depicted in old cartographic records up to the end of the $18^{\text {th }}$ century.

KeYwords: historical cartography, hydrographic objects, environmental features, Poland

Kaniecki A., Adam Mickiewicz University, Institute of Physical Geography and Environmental Planning,

Dziegielowa 27, 61-680 Poznań, Poland, e-mail: alkan@amu.edu.pl

In various types of analysis involving the areal and temporal variability of water conditions, it is necessary to refer the current state of affairs to those of the past. A big role is played here by old cartographic records, which are an important documentation of the knowledge of, and level of human interference in, the state of the aquatic environment of the given area in their time. In terms of geographical location, the best-studied feature, apart from settlements and roads, was the river network, which usually provided the basic orientation element in cartographic records. Hence old maps and plans are used as a significant and rich source of information about the structure of the hydrographic network, especially about the pattern and shape of the river network in the particular periods of its change, whether under the influence of natural or man-made factors. On their basis it was possible to trace changes in the courses of streams and the character of their channels as well as in the extent of natural water bodies, the presence of artificial reservoirs, the extent of wetlands, changes in the land-use pattern, and relief features.

This article seeks to make a survey of ways of graphic presentation of environmental elements in old cartographic records and to assess their reliability. Special attention is paid to plans as well as large- and medium-scale maps prepared until the end of the $18^{\text {th }}$ century.

The maps of Polish lands appearing from the first half of the $16^{\text {th }}$ century and depicting a hydrographic network as the base, starting with those by B. Wapowski followed by W. Grodecki and M. Kromer, contained many errors and showed poor accuracy, which was due to the fact that they were made at a scale smaller than 1:1,000,000. Generally, only the direction of the principal rivers was displayed relatively correctly. As has already been mentioned, the basic content of maps of those times was usually the river network; it was scribed first, and other ele- 
ments followed: settlements (towns, villages), relief (the hill-profile method) and forests (clusters of single trees). The methods of field measurements were not precise enough at that time to allow an analysis of the location of objects and their spatial changes by overlying information layers on contemporary maps. In spite of their lack of cartometric reliability and accuracy, they provide significant material for determining general characteristics of the hydrographic system.

The variety of ways of presenting environmental features employed in old, non-cartometric cartographic records makes them differ markedly in the scope of information conveyed. It has been found that for a detailed reconstruction of water conditions in the given area it is necessary to augment cartographic material with historical source materials as well as the results of archaeological, geological, and other studies (Kaniecki 1993).

For the Polish conditions, it can be assumed that a quasi-natural state of water conditions was that which occurred before the end of the $18^{\text {th }}$ century, i.e. before the start of larger-scale wetland drainage works and measures regulating river channels, which involved the lowering of the water level in water bodies and the straightening of their courses. Thus, the regulatory work in the upper Noteć reaches required by the construction of the Bydgoszcz Canal in the 1770s caused the level of Lake Gopło to fall $0.5 \mathrm{~m}$, while the building of the Upper Noteć Canal led to a further lowering of its waters by $2.88 \mathrm{~m}$. There was also a significant drop in the water levels of other lakes through which the Noteć passes. The use of maps from before the time of the big works regulating river channels and draining wetland or upland areas would help to reconstruct the natural courses of rivers and the old extents of lakes and wetlands, and thus their change as a result of the human impact. In the case of some regions of Poland, for example Wielkopolska, the sources of information about the state of the natural environment and its transformation from the $17^{\text {th }}$ to the late $19^{\text {th }}$ centuries include a great variety of Polish, but largely Prussian, cartographic collections. The most accurate and newest cartographic records present a natural environment strongly transformed in the other half of the $19^{\text {th }}$ century as a result of wetland drainage measures and works regulating the course of the river network.
The earlier cartographic records now in Polish archives and collections are of little accuracy and do not cover larger areas. Especially serious is the lack of large-scale maps, whose rich collections can be found in German archives.

Often presented on each plan or map predating the $19^{\text {th }}$ century are certain environmental features missing from other cartographic records. They make it possible to trace the dynamics of change in the environment or land-use pattern in the vicinity of a given town in a specified time interval. In the case of larger areas, however, we only practically have medium-scale maps: of poviats, voivodeships, parts of the state, or sometimes its entire area. Made at larger scales were only maps of small land fragments, e.g. roadsides (ribbon maps of postal roads) and riversides, courses of rivers along shorter or longer sections, or surroundings of towns. This concerns cartographic records until the mid- $19^{\text {th }}$ century.

Those were maps prepared at various scales, using various graphic and printing techniques, sometimes hand-drawn, differing in orientation and ways of presenting environmental features. At that time no uniform scope of the map content and symbology had yet been worked out, while preparation methods did not allow the inclusion of much detail. Still, those maps provide information that we are unable to obtain in any other way, and with a relatively small input of means and labour.

In the states of $17^{\text {th }}$ - and $18^{\text {th }}$-century Europe, an accurate map became a tool indispensable for ruling and conducting wars. As a result of the introduction of the triangulation method and new measuring instruments like the plane table and the theodolite, maps started to be much more accurate. At that time topographic maps at large scales were also drawn on the basis of detailed field surveys that included a much greater number of natural elements and objects. This especially concerned maps of towns and their surroundings as well as those of fragments of river valleys depicting their hydrographic situation. The bodies charged with conducting topographic surveys were general staffs because topographic maps were supposed to be used largely for military purposes (Buczek 1935).

There are relatively few large-scale cartographic records covering small areas, not to speak 
of large-scale maps embracing an entire state or at least one of its regions. There are no cartographic records covering extensive areas from before the time of formation and operation of water companies that would register little changed, or sometimes even natural, water conditions: a little changed river network, the extent of lakes and wetlands from before drainage works, and the presence of canals and artificial water bodies (e.g. post-mining, farming, mill-related, etc.).

More reliable are plans of towns and suburban areas compiled since the beginning of the $18^{\text {th }}$ century, usually at large scales. Authored as a rule by military cartographers, they displayed the most significant features connected with a town's defensive system: the course of moats, the nature of the defensive walls, entrenchments and bastions, access roads, river crossings, and major buildings. They were usually correct in depicting the location of churches and other facilities in the town itself as well as the courses of streams in its direct vicinity, but their accuracy decreases with the growing distance from the town. In the case of Poznan, none of the $17^{\text {th }}$ - and $18^{\text {th }}$-century plans of the town, and we know more than ten of them, does not seem fully reliable if studied separately, as H. Münch (1937) pointed out a long time ago.

Thus, it is necessary to reach the information conveyed by those old cartographic records and use it, or even better, to publish fragments of collections stored in the archives of other states. There are especially many maps from the $18^{\text {th }}$ century and the first half of the $19^{\text {th }}$ in the Stastsbibliothek zu Berlin, which in 1919 took over the collections of the Grand General Staff dissolved at that time. Rich cartographic collections can also be found in the Geheimes Stastsarchiv Stiftung Preussisches Kulturbesitz in Berlin-Dahlem and in the Zentrales Stastsarchiv in Merseburg. In the case of Wielkopolska or its parts, these are maps by T.P von Pfau at a scale of 1:87,500 published in 1778 and by F. von Schmettau prepared in the years 1767-1780 at scales of 1:24,000 to 1:90,000 (Madej 1987). Besides, there appeared other maps of Wielkopolska designed after it had been annexed by Prussia as part of the partition of Poland.

Precise field measurements based on triangulation opened the next period in the development of topography. In Wielkopolska the first plane- table map (Ur-Messtischblätter) prepared on the basis of triangulation fixes at a scale of 1:25,000 started to be published in the 1830s (Jankowska 1993). The map largely depicted objects important from the military point of view, i.e. roads, streams, water bodies divided into lakes, ponds and emptied ponds, dry and wet ditches, seven kinds of bridges, water mills and windmills, meadows and marshes longer than 400 steps (i.e. about $300 \mathrm{~m}$ ), and major buildings. In addition to the unification of symbology, descriptions were also made uniform, with the size of lettering depending on the size of the objects depicted (water bodies, streams, dunes, valleys, islands, dams, mountains, etc.). However, spot heights were not marked. The relief is presented using a method worked out by von Müffling and involving a combination of lines - thick, thin, wavy and dashed, depending on the slope angle of the land (Jankowska 1993). This is a very plastic map; it was a great advance in comparison with those made before. Still, it is not fully cartometric yet. But this is another story. Those maps can be found in the Staatsbibliothek Preussisches Kulturbesitz in Berlin (Kaniecki 2007).

The maps considered to be fully reliable and able to provide a basis for detailed studies of environmental changes are Prussian topographic maps at a scale of 1:25,000, the so-called Messtischblätter, published for the area of Wielkopolska in the 1880s. They present a natural environment strongly transformed in the second half of the 19th century as a result of intensive wetland drainage and regulatory works in the river network. In the years 1842-1890, about 300 water companies were set up in the Poznan and Bydgoszcz districts aiming to change wetlands or some lakes into pastures or meadows (Paluch 2006). Major rivers, like the Warta, Noteć, and partly Prosna, were adapted for navigation, while medium-sized and small streams were included into the drainage system. Also, the extent of lakes changed as a result of the drainage work performed.

For the Russian partition, the first fairly accurate cartographic source is the Topographic Chart of the Polish Kingdom prepared in 1843 at a scale of 1:126,000. The relief on this map is presented using Lehmann's hachuring method.

In principle, when analysing hydrographic networks and water conditions, we distinguish 
two kinds of map. The first includes small- and medium-scale maps presenting the river network pattern in the given state, or one big river. They are usually general-reference maps. Examples of such maps for Poland are J. Freudenhammer's Mapa Palatinans Posnaniensis from 1645 at a scale of about 1:460,000, maps of the Dnieper by G. Beauplan at scales of about 1:232,000 and 1:464,000 from the late 1740s, Carte de la Pologne .. by G. Rizzi-Zannoni from 1772 at a scale of about 1:692,000, and especially a hydrographic map of Poland by Karol de Perthees at a scale of about 1:350,000 from 1785 and, by the same author, an atlas of Poland's voivodeships at a scale of about 1:225,000, prepared in the years 1783-1804 (Madej 1987).

The other type of maps of inland waters, according to H. Musall (1986, after Graf et al. 2008), are those at large scales prepared for urban areas and their adjacent zones, or for selected fragments of a river network, usually in situations of conflict about property boundaries, or as a documentation of planned hydraulic works, like river regulation, the construction of levees, or a drainage network.

\section{Assessment of the objectivity of medium-scale maps}

Until a widespread use of the triangulation method, i.e. the end of the $18^{\text {th }}$ century, the accuracy of river courses in old cartographic records was connected with the accuracy of presentation of towns and settlements in whose neighbourhood a river flowed. In the opinion of Madej (1987), the accuracy of the river network in old maps should be considered either relative to localities or to the cartographic grid, because the latter was not always defined precisely. That is why in old maps physiographic elements should be considered separately from geographical coordinates. Not infrequently, one can find discrepancies between the situation of a river in the field and its drawing on a map.

Depicted most correctly are those segments of rivers that are in the vicinity of a dense settlement network which provides reference points for them. The courses of river segments with more sparse reference points often depart from reality. The general stream direction is usually shown correctly, although often shifted in relation to the cartographic grid or settlement network. In the case of lowland rivers with their meandering courses, numerous arms and branches, low longitudinal gradients, and the resulting presence of many oxbow lakes, one can hardly speak of an accurate mapping of their changing course. The inaccessibility of valleys, especially big ones, owing to their marshiness, limited the exploration of stream courses to their most important elements. Even the determination of the course of the principal channel of such a stream was sometimes impossible. Thus, an analysis of the course of main streams on maps from this period, at least on medium-scale ones, show it to be depicted relatively accurately, but what presents a problem is, for example, finding their sources in sometimes extensive marshy areas. That is why it is only possible to indicate the course of a river on those maps in a descriptive way, because their authors usually had no data that would be fully reliable. Often the designers of those old cartographic records depicted a river network in a purely fantastic way, with numerous arms, branches or tributaries whose traces can hardly be found today, whether in the field or on accurate maps. This situation lasted sometimes to the beginning of the $19^{\text {th }}$ century.

We usually do not remember how inaccessible river valleys used to be, both of small and big streams. This inaccessibility resulted primarily from the water-logging of those areas, the presence of back-swamps, oxbow lakes, and sometimes several arms of the principal river. The latter, shallowly cut into in the floodplain, often changed its course during floods. Channels were blocked up with trees brought by a flood; as a result, there formed local dams causing a channel to change its course, or to branch. The many oxbow lakes and marshes still existing on the Warta floodplain are proof of the former course of the river and its arms. The poor passability of rivers and their generally poor ability to drain groundwater from valleys facilitated the formation of waterlogged areas and marshes. This permanent water-logging was a common element of valleys, especially of larger rivers, often making them impossible to cross. There were much more small streams and water bodies in the valleys then. 
When describing the former channels of the Warta and the Noteć in their lower reaches, Surowiecki (1811) presented them as meandering rivers divided into a multitude of arms occupying practically the entire floor of the Noteć Pradolina. In the spring, during floods, there formed huge bodies of stagnating water (Kaniecki 2007). An example is provided by the lower reaches of the Warta, mapped in 1773 and 1786 in connection with the regulation of its channel for navigating purposes. The two maps are:

- Karte von der Netz und Warthe Bruche, made in 1773 by an unknown author at a scale of about 1:50,000 and presenting the hydrographic network in the lower reaches of the Noteć Pradolina, now in the collection of the Ossolinski National Institute in Wrocław (Fig. 1), and

- D.K. Sotzmann's map of the same area, made in 1786, now in the collection of the Poznan Society of the Friends of Sciences (Fig. 2).

At that time the Bydgoszcz Canal waterway joining the Vistula and Odra river systems was under construction. Both maps present the picture of the Warta valley and channel in the second half of the $18^{\text {th }}$ century, when the river flowed divided into several branches in a wide, marshy valley, forming numerous oxbow lakes and bodies of stagnating water, which showed the river to be unregulated and emphasised the great complexity of its system. The Warta was regulated in the years 1767-1785 and the works included the drainage of riverside meadows, the construction of a rampart about $3 \mathrm{~m}$ high along the Gorzów Wielkopolski-Kostrzyn section, and a change of the Warta mouth with the construction of the present river channel, the so-called Friedrich Wilhelm Canal. In the years 1785-1787 a new channel was dug, and the mouth, formerly situated south of the Kostrzyn's Old Town, was moved to the north (Graf et al. 2008).

The two maps whose fragments have been presented above are hand-drawn, with the 1773 one made at a higher editorial level, mainly because of the use of colour, carefully executed descriptions and vegetation pattern, and the shading of the margins of islands on the Warta

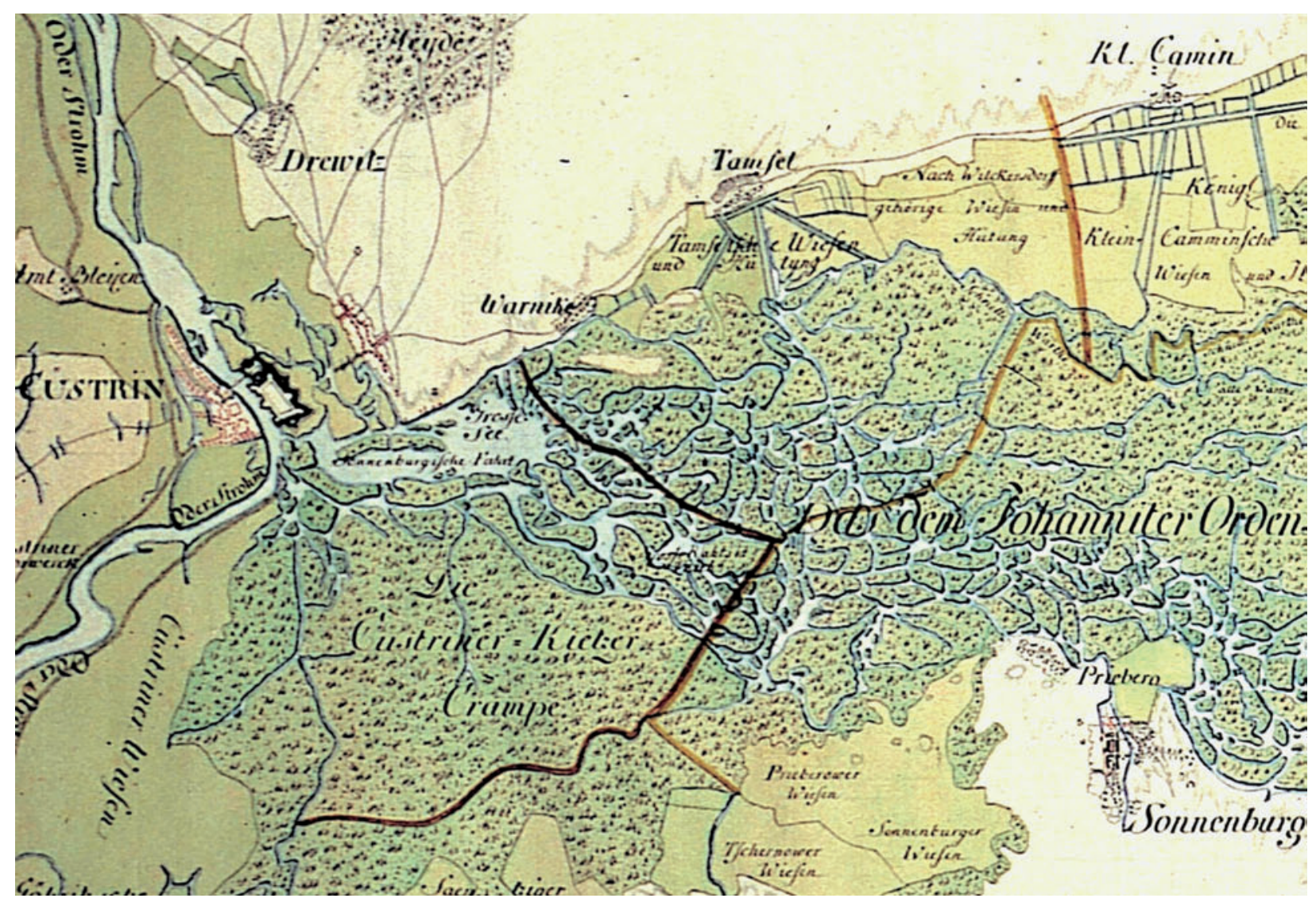

Fig. 1. Unregulated hydrographic network at the mounth section of the Warta in 1773. Fragment of a map from the collection of the Ossoliński National Institute in Wrocław 


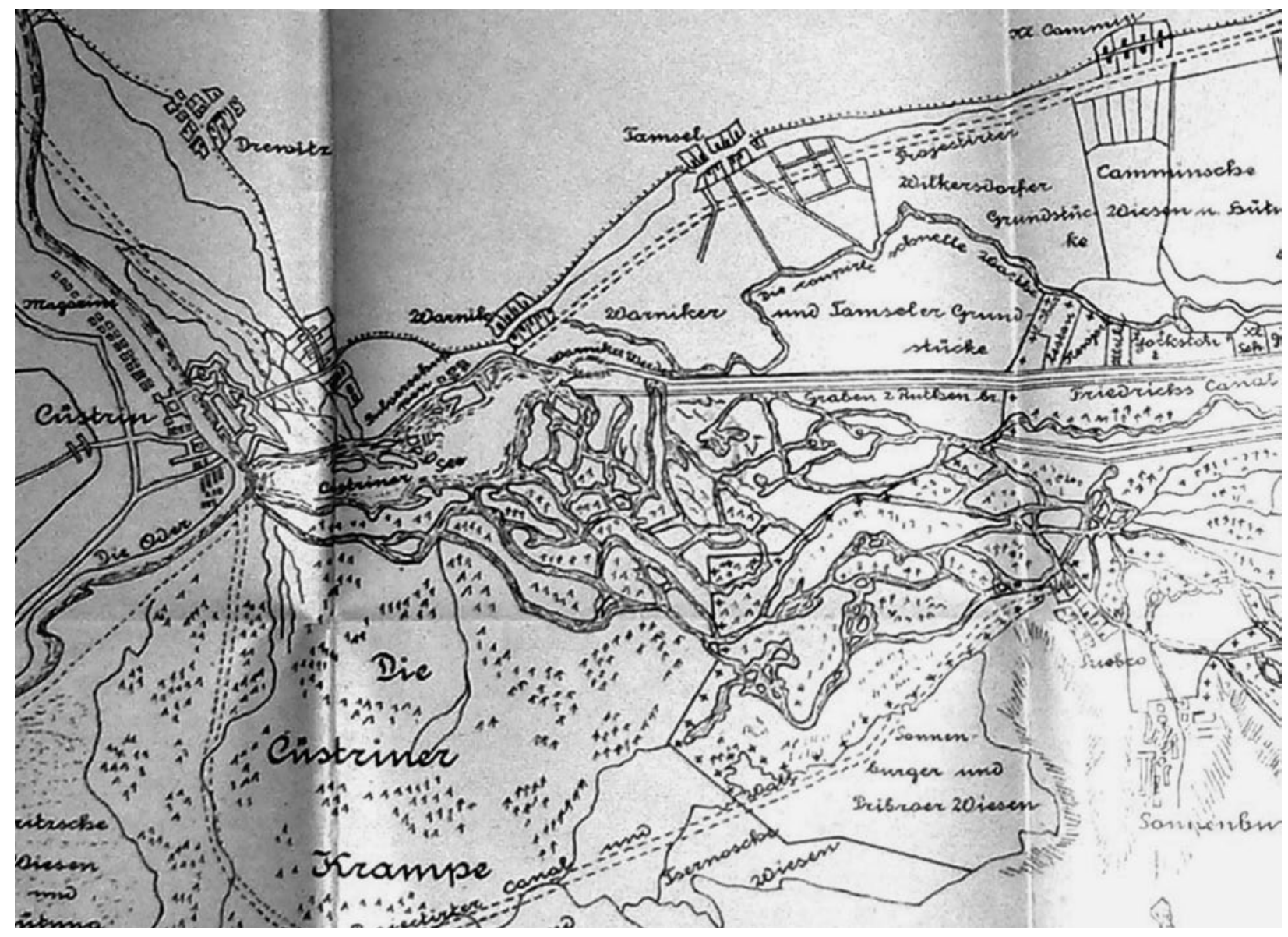

Fig. 2. A reducet fragment of a D.K. Sotzmann map Das Warthe Bruch mit Bevorhebung Des Deich und Canalsystem.. from the collection of Poznańskie Towarzystwo Przyjaciół Nauk in Poznań

back-swamps. The map also shows the land-use pattern and the distribution of settlement units. Sotzmann's 1786 map, in turn, can rather be treated as a field sketch.

When comparing the two $18^{\text {th }}$-century maps, one can see that their river network patterns are similar, primarily because they do not distinguish the principal Warta channel. All the river branches are presented as linear and areal elements of similar width, though irregular contours. Such a graphic presentation reflects the general character of the hydrographic system, but the essence of this analysis is the cartometric reliability of those two sources. Here it concerns measurable parameters, like the number, length and width of branches, width variations (the area of the water surface), river sinuosity, and main directions of water flow. Both maps depict Lake Kostrzyńskie (Grosse See - 1773, Custriner See -1786) in the area adjacent to the Kostrzyn fortress, but its shape, area and extent differ considerably. There are also differences in the size and shape of islands shown on the lake. The 1773 map situates Sonnenburgische Fahrt, one of the larger and more characteristic branches of the Warta, within the Grosse See.

More precise conclusions concerning differences and similarities in the presentation of the content and ways of mapping hydrographic elements can only be drawn at the next stage of the cartographic research method. Here it involves a comparative analysis of the two hydrographic systems superimposed one upon the other. A broader analysis of those comparisons as well as the vectorisation of the river network has been presented in an earlier study (Graf et al. 2008).

Characteristic of the state captured in 1786 (green) is primarily a smaller number of streams and markedly wider channels than in the 1773 image (red). Generally, one can find big differences in the course of the river system in the lower reaches of the Warta. Sotzmann's map presents a greater number of water areas, which need not follow from the actual state of affairs, 
but rather from the way of drawing adopted by the author. In turn, the shading of the margins of stream channels by the author of the 1773 map certainly enhanced its plastic value, but on the other hand has made it difficult to determine the width of river arms. Since both records lack cartometric reliability, it is impossible to make an unequivocal quantitative characterisation of the hydrographic network, for example to establish the number and length of streams or changes in the density of the river network over the periods the maps refer to. In turn, the high level of complication of the river network, with the channel of the principal stream not distinguished and no possibility of determining the geographical location and altitudinal ordinates of hydrographic objects, does not allow any analysis of the sinuosity and development of the river, or a change in its gradient downstream (Graf et al. 2008).

On the basis of a comparative analysis of the way in which the Warta mouth is presented on maps, even made at the same time, one can state that a significant role was often played by the author's fantasy, the drawing manner he adopted, and whether this area was mapped during highor low-water stages in the river channel (Graf et al. 2008).

\section{Assessment of the reliability of large- scale maps}

The other type of maps of inland waters are detailed ones, prepared at large scales for selected fragments of a river network or as a documentation of planned hydraulic works, like river regulation, the construction of a canal, etc. Here we can also distinguish plans of towns and their suburban areas, including the hydrographic network. In fact, each major Polish town has got at least a few plans or views coming from the $17^{\text {th }}$ and $18^{\text {th }}$ centuries. The first strictly cartographic plans of Poznan, still preserved, come from the mid $-17^{\text {th }}$ and the beginning of the $18^{\text {th }}$ centuries. Compiled by Swedish, Saxon and French military cartographers, they described the most salient features of the town's defensive system: walls, moats, entrenchments, bastions, the river network in the town's direct vicinity, river cross- ings, access roads, and sometimes major facilities, e.g. churches.

While the first plans or views of the town showed it in a way defined by the author, without the use of measuring instruments, $18^{\text {th }}$ century cartographic records at least relied on a plane-table survey, and the topographic and hydrographic situation presented in them is close to the actual state of affairs. Still, old cartographic records often contain mistakes or depart from reality, which follows from both, the imperfection of methods or measuring instruments and from the incomplete image of the town obtained from the point where the mapping was performed. When presenting the problem of the diversity of ways of graphic presentation of hydrographic elements in cartographic works of various ages, use was made of analyses made in earlier studies (Kaniecki 1993, 2007, Graf \& Kaniecki 2008, Graf et al. 2008).

The following issues are considered when assessing environmental conditions presented in old plans:

- how far is the river network reliable?

- what are the differences between ways of presenting the most important elements of the hydrographic network, i.e. its pattern, course of branches and arms, oxbow lakes, etc.?

- what methods of graphic presentation were employed to visualise river channels themselves, depicting such of its features as the depth of incision into the floodplain, the presence of point bars, etc.?

- how was the direction of streamflow indicated?

- what hydraulic structures were presented in those plans?

- in what ways were the types of water bodies presented and how their number or size changed in various plans?

- in what ways were wetlands presented that were part of the town's defensive system in its direct neighbourhood, and were they differentiated in terms of use (meadows, pastures, wasteland, etc.)?

- how were the major relief elements presented: scarps, river valleys, extent of residual forms of higher terrace levels in the Warta valley, differences in the floodplain surface, etc.? 
- in what ways was higher- and lower-lying land presented?

- how were grassland and vegetation-free areas presented, as well as arable land and pastures?

Out of the environmental elements, water and relief were the chief content of $17^{\text {th }}$ - and $18^{\text {th }}$-century plans of Poznań. The hydrographic situation, as has been mentioned, involved the channel system and flow of the Warta river and its branches and tributaries: the Cybina, Bogdanka and Wierzbak. The topographic situation, in turn, was mainly depicted through the system of terrace levels within the Warta valley, including the situation of isolated eminences: the Castle Hill, St. Martin's Hill, St. Adalbert's Hill and Bald Hill, as well as the extent of wetland. Presented against this background were the locations of various infrastructural facilities of the urban system, which provided a basis for an assessment of spatial relations holding among the individual elements of the natural environment (Kaniecki 1993).

The spatial scope of the present study is generally limited to the town's historical area and its immediate neighbourhood: the valleys of the Warta, Cybina and Bogdanka (Fig. 1). The oldest part of Poznan - the right-bank Ostrów Tumski (Temple Island) - was built in the mid- $10^{\text {th }}$ century on the floodplain of the longitudinally oriented gorge segment of the Warta valley cutting across a ridge of end-morainic hills of the Poznan Stadial and a morainic plateau. In turn, left-bank Poznań started to be located in 1253 on terrace level II, which only survived in a small fragment adjacent from the south to the Bogdanka valley.

The Warta valley in Poznan is deeply incised into the morainic plateau. Its slopes, especially the western ones, rose at a steep gradient from the valley floor and were often inaccessible. As a result of the slope steepness in the gorge section of the Warta valley, since the Palaeolithic times settlements were located mostly in the valleys of its tributaries where wide, gentle slopes facilitated communication. Out of the higher terrace levels in the Poznań vicinity, terrace VII and parts of VI and IV on the right-bank side of the valley still survive. Clearly marked in the town's relief are also deeply incised old valley forms, roughly latitudinal in their course, now occupied by the Bogdanka on the left of the Warta valley and the Cybina and Główna on the right. Where the oldest Poznan was situated, the Warta floodplain was relatively narrow and the river split into several arms and branches between which islands had formed, making river crossing easier (Fig. 1).

An analysis of geological, archeological, cartographic and historical materials showed that the lowest part of the Warta valley, i.e. its floodplain, was not a flat surface covered with alluvial deposits. Until recently it held remnants of higher terrace levels, which were finally liquidated mostly as a result of intentional human activity in various periods of the town's development. Apart from the eminences that have survived until today as St. Adalbert's, St. Martin's and the Castle Hills, there also used to be the Bald, Golden, Capitular and Bachelor Hills. Unnamed residuals were also on Chwaliszewska Island, in the northern part of Ostrów Tumski, and in the village of Rataje. The floodplain itself did not stand much above the average water level in the Warta and was occupied by water meadows. There were also shallow, periodic water bodies - back-swamps left by the Warta floods. Adjacent to the town on the north, within the Bogdanka valley, was a wetland called the Dominican or Groffowe Meadows. Within the stronghold itself, the town and the suburban settlements situated on the lowest terraces, the land level was successively being raised since the beginning of their existence through intentional buildup or through the accumulation of cultural layers, which was a protection against the Warta floods (Kaniecki 1993).

In the article use was made of four views and plans of Poznan dating from 1615 to 1772 on the basis of which it is possible to trace changes in the pattern of the river network and sometimes the topographic surface of the town and its suburban zone. Some results of those analyses were presented in an earlier study (Graf \& Kaniecki 2008). Those are:

- a perspective view of Poznań from G. Braun and F. Hogenberg's Civitates orbis terrarum, vol. 6, Cologne (coloured copperplate),

- a plan (engraving) by P.S. Fabbert (Belagerung der Stadt Posen von den 4 bis 24 October Anno 1704),

- a "Saxon plan" of Poznań (plan de Posen) from 1734, and 
- the Plan von der Stadt Posen, ascribed to S.F. von Geyer, from about 1771-1772.

The plans differ in the range of information conveyed, which follows from both, the measuring techniques employed and the scale and technique of graphic presentation of elements of the natural environment and the spatial orientation of the given record. Some of the plans were drawn from St. Adalbert's Hill, while the rest from the town hall tower; hence, owing to some parts of the town not being fully visible from those vantage points, they do not contain complete information (Wagner 2002).

\section{The perspective view of Poznan from the work by G. Braun and F. Hogenberg Civitates orbis terrarum, vol. 6, Cologne, 1618 (coloured copperplate)}

This view of Poznań from about 1618 (Fig. 3 ) follows the principles of landscape painting of those times in combining elements of a plan and a panorama. It is a fine engraving by an author unknown, depicting Renaissance Poznań at a time when it flourished, with some elements of the natural environment. It is a very valuable document from the town's past, painted by an eye witness and of great artistic and cognitive worth. It amazes one with the richness of infor- mation concerning both the layout of the town and its suburbs, the look of major objects, and the topography and hydrography of the area. Distinctly marked are both the river network and the relief. The view is oriented south.

The view of the relief from the north, probably from St. Adalbert's Hill, is limited in the left-bank part of Poznan to the presentation on a colour base of an isolated two-level eminence, the so-called Castle Hill, and in the right-bank part, of small knolls in the northern part of Ostrów Tumski and Chwaliszewo, i.e. on the floodplain. What it does not depict are the steep scarps of the Warta valley, especially the western scarp running from St. Martin's Hill along the present Półwiejska Street. Relief features are marked with colour (brown, sepia) of little contrast. A darker colour depicts more elevated land (hills), while a lighter hue is used for roads in its vicinity and the area of the town itself, with the market and town hall, surrounded by town walls. The plan presents an image of the town seen from above at an angle of $60^{\circ}$ in which slopes are marked by hachures of various length and thickness.

Hachuring was also employed to make the picture of banks of the Warta and Cybina channels more plastic (Fig. 3). The great density of vertical dashes in their bank zone conveys information about a deep incision of the channel into the floodplain. The streams assume the form of ribbons of various sinuosity whose blue-coloured area is filled with horizontal hachuring.

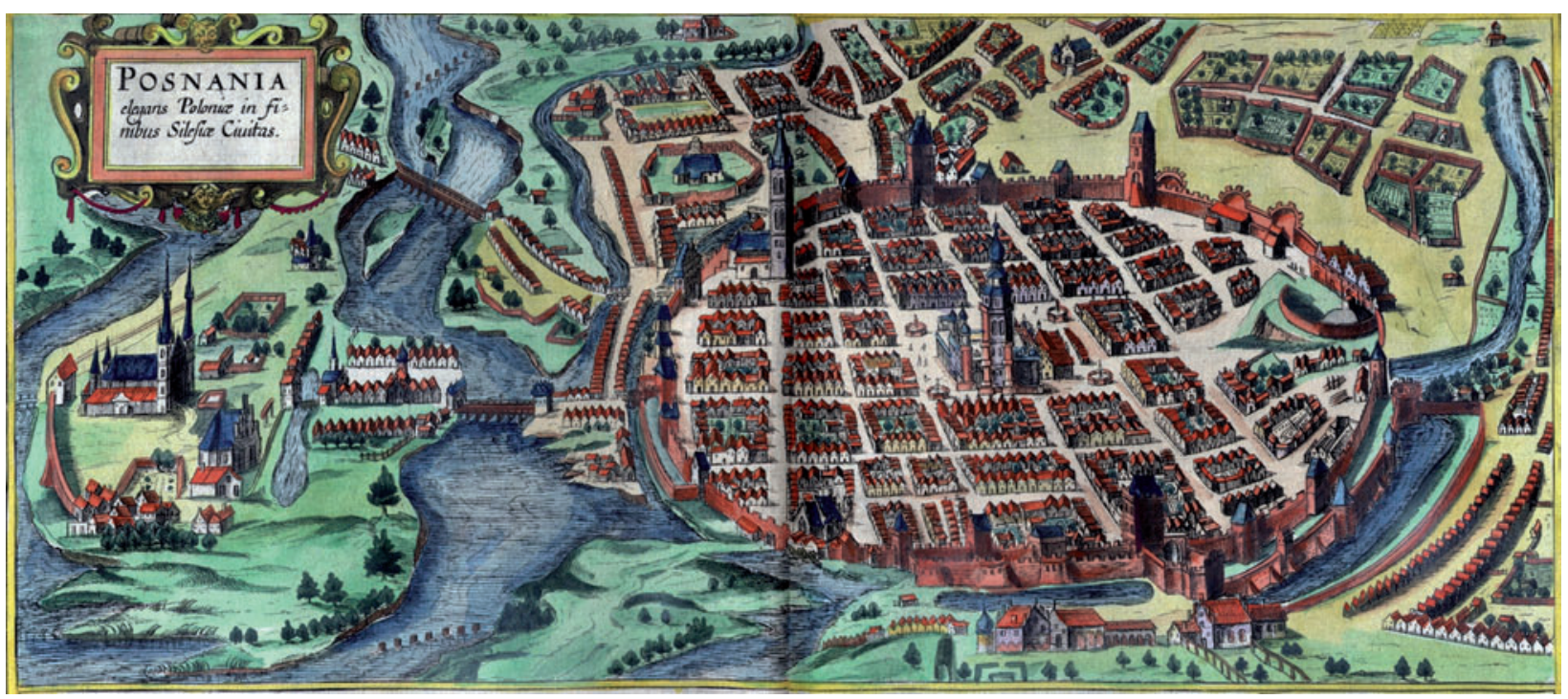

Fig. 3. A vista of Poznań from 1615, reproduced from G. Braun and F. Hogenberg: Civitates orbis terrarum (a coloured cooperplate print) from 1618, Cologne 
The plan also shows the course of the Bogdanka, a left-bank tributary of the Warta, which comes to Poznan from the west. Before the town walls it nourished the wide moat and then its waters were directed to the Warta by a narrow crosscutting near the Dominican monastery. The elements supplementing the content are bridges on the Warta (Chwaliszewski and Great) and on the town moats, as well as the Great Mill located near the mentioned monastery. The piles driven into the bottom of the channel above the Great Bridge were a basis for the construction of dams or temporary weirs built of brushwood, clay and stones that served to dam water during low-flow stages in order to prolong the time of operation of mills situated on the river. Also marked are sandy islands in the Warta channel near the Great Bridge (Kaniecki 1993).

The hydrographic system presented in the 1618 view shows a wealth of detail, but the accuracy of mapping the real situation is low. This concerns both, the number of the streams depicted and the geometry of their channel forms, e.g. the width or the location of mid-stream islands. The interpretation of the Warta system itself is wrong, especially of its western branch flowing round Grobla Island. Besides, two of its branches are missing altogether: one, called the Noteć, nourishing the moat near the Wrocław Gate, and another, called the New River at the start of the $17^{\text {th }}$ century, flowing in the eastern part of the Warta valley, above the Great Bridge. The Warta flows divided into two arms, of which the eastern one is marked as the principal channel, similar in its course to the contemporary one from the period before it was moved in 1969. The western arm, flowing round Grobla Island above the Bernardine monastery, did not join the Warta near the Great Bridge (situated higher on the plan), but the painter had included its part into a branch later called the Struga Karmelicka. Chwaliszewo is separated from Ostrów Tumski by a closed, marshy depression without an outlet, a former Warta channel, the so-called Old River. This suggests that at the time when the view was painted it performed the function of a floodwater channel carrying waters only once in a few years, and mostly during higher floods.

In later cartographic records, always depicted between those floodplain islands is a passable hydrological system. Town moats are presented very suggestively. The road leading to the Great Mill is lighter in colour than the rest of the grasscovered land, which shows it to be a rutted dirt road, not surfaced with stone or wood (Kaniecki 1993).

The 1618 view, despite its distinct visualisation of elements of the hydrographic network and relief, is not too accurate, hence it cannot provide a basis for an analysis of changes in the natural environment of the town of Poznań.

\section{Plan (engraving) by P.S. Fabbert (Belagerung der Stadt Posen von den 4 bis 24 October A. 1704) from 1704}

This plan (Fig. 4) is east-oriented and presents the town of Poznan within the boundaries including its left-bank part surrounded by walls and a system of moats, and the right-bank part with Ostrów Tumski and Śródka, as well as the islands of Chwaliszewo and Grobla. The picture also includes the land adjoining the town, but in this case elements of topography and hydrography are presented in a highly general way.

The diversified relief is presented on a colour (light yellow) base with the help of hachuring, which was employed, among other things, to mark the western and southern slopes of the Warta valley as elements dominant in the orography of this part of the area. The steepness of the Warta valley scarps was conveyed by a higher density and thickness of hachures. This technique was also used to mark the highest terrace levels assuming the form of isolated elevations: the Castle Hill in the western part of the town and St. Adalbert's and the Bald Hills in its northern part. Their top parts are free of hachuring, which, in accordance with the rules of this method, means a relatively flat surface. An element that stands out in the relief is also a defensive earthwork located in the Bogdanka valley, one of the several erected at that time on land adjacent to the town.

The hydrographic network of the town of Poznan presented on the plan, however, is not reliable, as some arms and branches are missing, including the Warta branch flowing round Grobla Island, the one separating the islands of Chwaliszewo and Ostrów Tumski, and the Cy- 


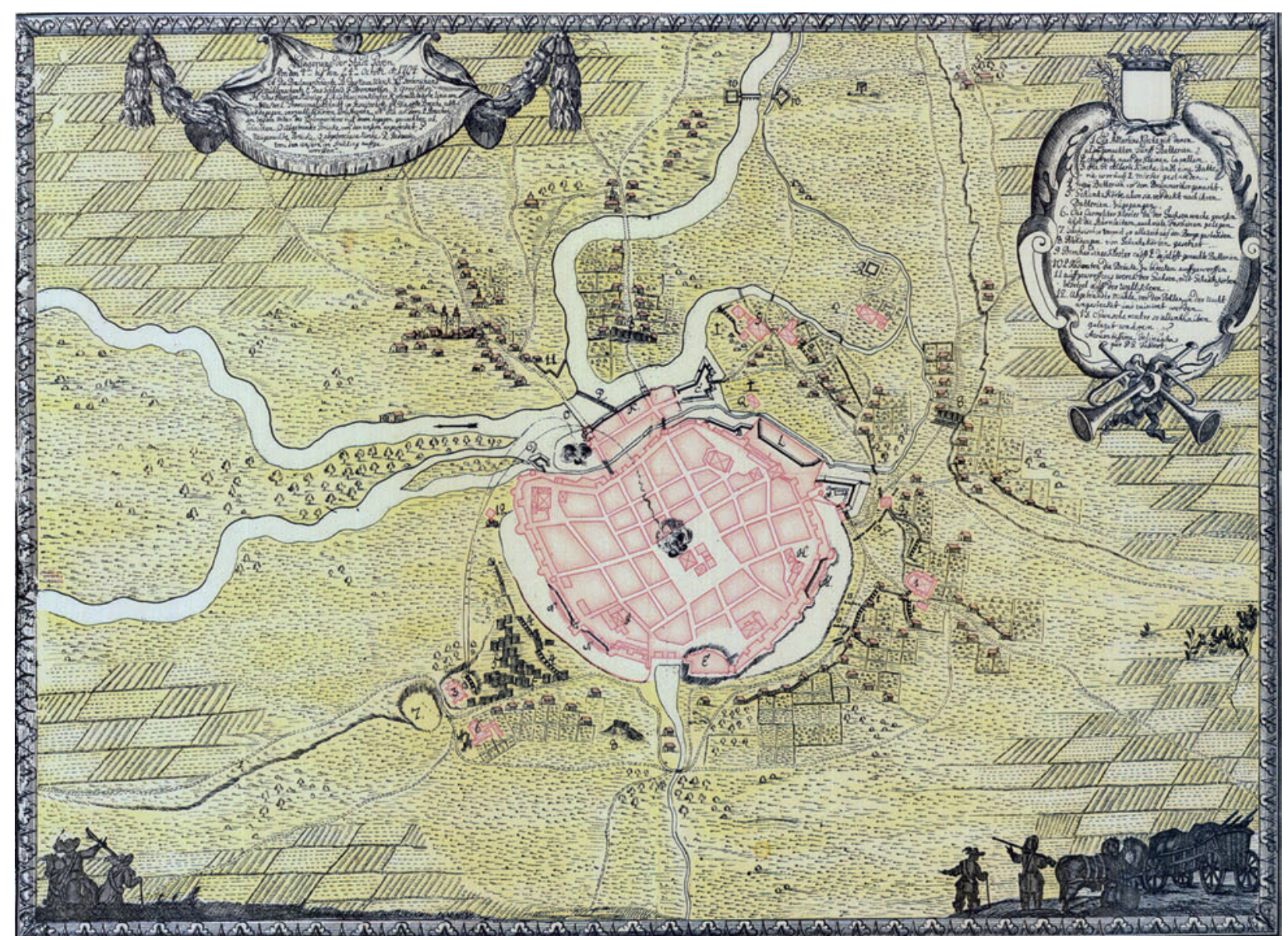

Fig. 4. P.S. Fabbert's plan of Poznań from 1704 (Belagerung der Stadt Posen von den 4 bis 24 October A. 1704)

bina. Streams are presented as ribbons of varying width, without any colour filling or hachures; in the case of the Warta, its flow direction is marked with an arrow (Fig. 4). An element additionally appearing on the plan are waterlogged areas, usually used as riverine meadows and pastures, whose identification is made possible by horizontal dashes. One can also locate tree-covered zones and cropland. The land in agricultural use situated in the Warta valley was probably former moorland, brought into cultivation under the socalled Moordammkultur project. Those were areas, crisscrossed by a dense network of drainage ditches, covered with organic soil that had formed from material coming from the deepening of the ditches and put along them, thus raising the level of the cultivated land. A different style of hachuring is employed to mark small plots of land used as gardens in the direct vicinity of the town.

Among the additional elements presented in the town plan one should mention the Chwaliszewski Bridge and one near Obrzyca, as well as the Capitular Mill on the Warta and the burnt Great Mill near the Dominican monastery.

\section{The "Saxon plan" of Poznań (plan de Posen) from 1734 (author unknown)}

The first accurate plan of Poznan is the socalled "Saxon plan" (Fig. 5), oriented north, which presents in some detail the topographic and hydrographic situation of the town and its nearest vicinity around the year 1734 . In its construction use was probably made of then advanced instruments allowing distance and height measurements, hence it differs in both, its information content and the accuracy of mapped elements of Poznań's natural environment from earlier, especially $17^{\text {th }}$-century, plans of the town. It was crafted very carefully by an anonymous Saxon, possibly military, cartographer in connection with the war of the Saxon succession. In its making the plane-table method was employed. 


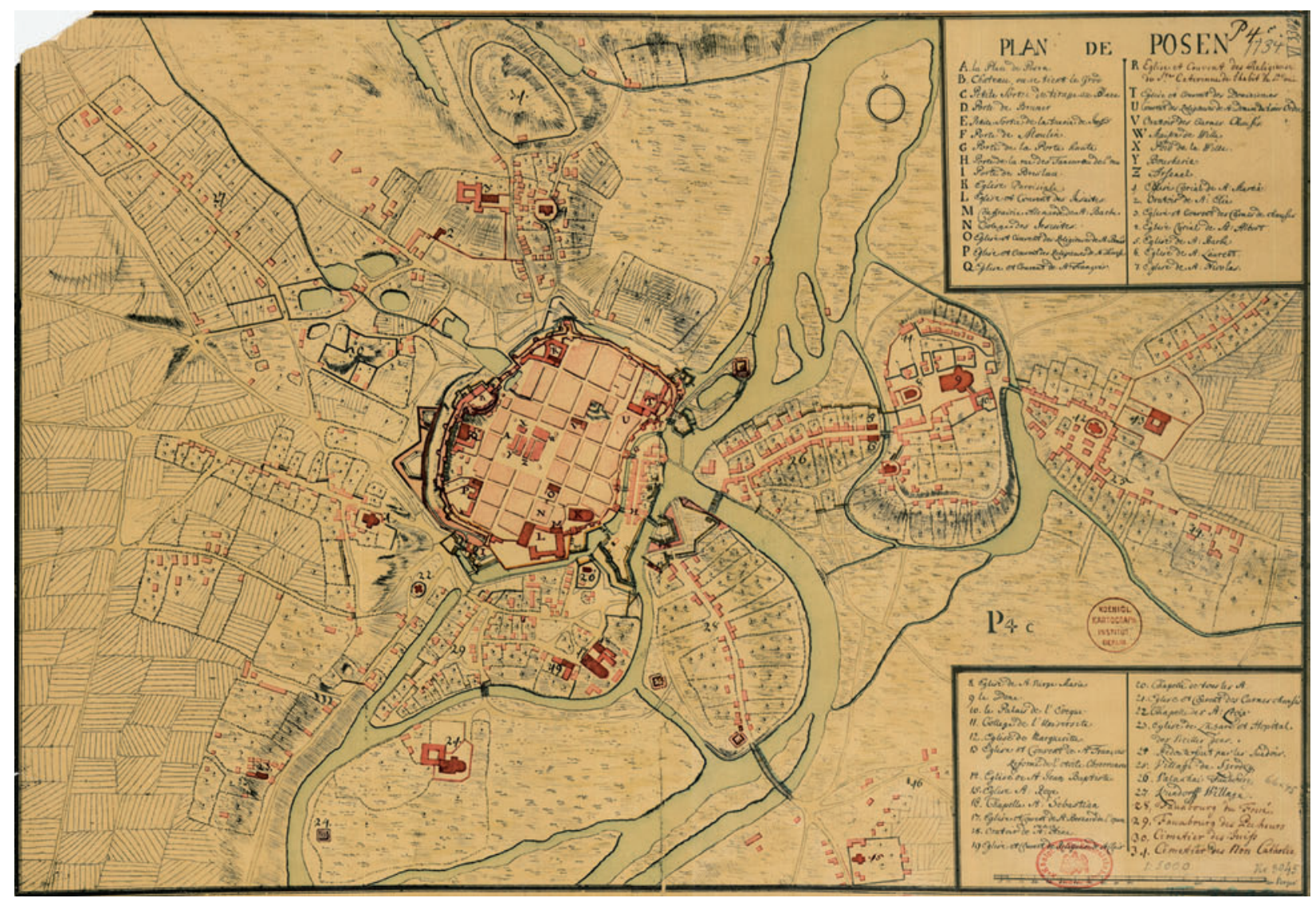

Fig. 5. A plan of Poznań (plan de Posen) from 1734 (by unknown author)

To present the relief, use was made of hachuring, here conveying quite faithfully the differences in the hypsometric conditions within the Warta valley and in the directly neighbouring zone. Hachures perpendicular to the river channels depict scarps of the terrace levels of the Warta and Bogdanka valleys. Clearly marked are also the isolated Castle, St. Adalbert's and Bald Hills, as well as land elevations on the floodplain settled as a result of land buildup, viz. Ostrów Tumski, Grobla and Chwaliszewo. Also presented is the Golden Hill, located between the Discalced Carmelites' chapel in Żydowska Street and the Dominican monastery, a two-level residual of a higher terrace level not included on earlier maps. The name of the hill survived in that of a street, no longer existing; it is also mentioned in source texts as a Goldenberg, or a Jewish Hill (Mika 1960). It was liquidated either in the late 18th century or after the great fire of this part of the town in 1803.

The relief in the "Saxon plan" is also differentiated by colour. In the technique of the graphic presentation of environmental content adopted by the author, a lighter colour depicts land lying higher, whether naturally or artificially, i.e. drier (Fig. 5). In this way the author clearly marked the highest portions of the mentioned islands on the Warta floodplain. A darker colour denotes land of greater moisture content, i.e. usually situated within depressions.

As to the elements of the hydrographic network, faithfully depicted are the courses of the Warta with its branches, the New and the Old River, in the southern part of the area, the branch separating Chwaliszewo and Ostrów Tumski, the Noteć connecting Rybaki with Garbary, the Kamionka, Cybina and Bogdanka rivers with water reservoirs at the Folusz mill, and fragments of the Wierzbak, flowing along the northern slope of the Bogdanka valley. In their presentation use was made of linear symbols (a ribbon) of varying width, filled with light-green colour. Also presented are water bodies situated largely in the Bogdanka and partly Wierzbak valleys, with hachures of varying density in their bank zones, thus marking differences in their steepness. The hydrographic network of Poznan is supplement- 
ed with elements of the artificial drainage system: moats and wastewater canals, mostly collecting waste from the entire town area.

On the plan it is also possible to determine the spatial extent of grassland, usually functioning as meadows and pastures. Those elements are marked with the yellow colour and horizontal hachures of varying intensity, depending on the soil moisture level. The highly waterlogged meadows filling the lowest-lying sites in the Warta valley, called the Groffowe or Dominican Meadows, are presented in yellow of greater intensity and contrast. The boundaries between the waterlogged pastures and agricultural land are clearly marked with a solid line.

As a result of drainage and land buildup, some of the wetland of the suburban zone was transformed into arable land. This is how the plan presents the area along the town moat between the Wroniecka Gate and the Warta that was raised in this way. We know from $15 \mathrm{t}^{\mathrm{h}}$ - and $16^{\text {th }}$-century source materials that this site used to be occupied by ponds drawing water from the town moat (Kaczmarczyk 1924).

The plan also shows in detail the town's defensive facilities, both those intended to protect the town itself, viz. walls and moats, and those protecting its foreland, like entrenchments, redoubts, bastions, etc. They were located just outside the Wrocław Gate, on Grobla, and near the Corpus Christi and Dominican churches. When constructing the great earth bastion in front of the Wrocław Gate about 1704, the Warta branch called the Noteć, whose waters supplied the town moat from the south and east, had been filled in. Since then the moat was supplied through a specially dug canal running from Garbary in the east and functioning as a moat of the Garbary entrenchment (Kaniecki 1993).

The "Saxon plan" is the first one to present in a fairly reliable way the relief, hydrographic network and water conditions in the town and its adjacent areas.

\section{Plan von der Stadt Posen, attributed to S.F. von Geyer, from about 1771-1772}

This plan (Fig. 6) is west-oriented and covers a decidedly larger area than the earlier records,

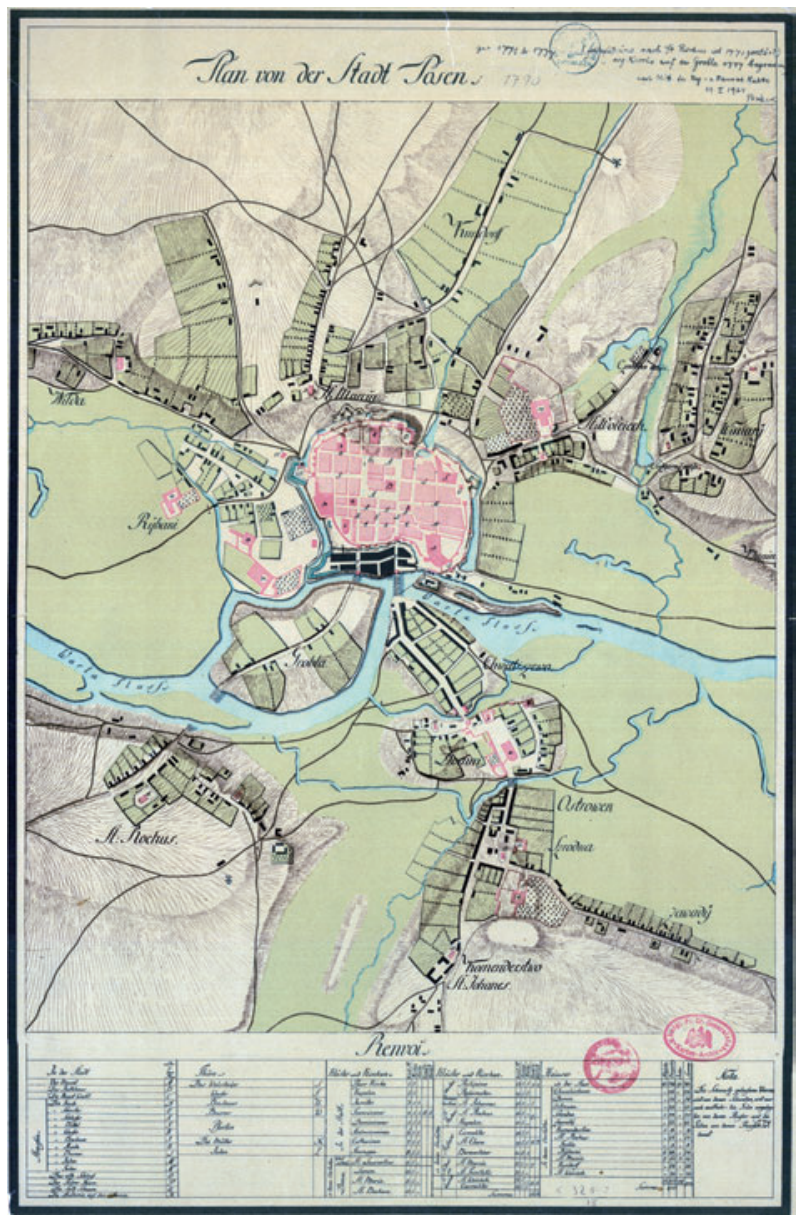

Fig. 6. A plan of Poznań from about 1771-1772 by S.F. Geyer which makes it possible to perform a wider spatial analysis of differences in the environmental elements of Poznań's urban and suburban zones. It is ascribed to a Prussian cartographer S.F. von Geyer, mostly active in Austria and Bohemia. In 1770 he entered the service of Frederic the Great and, perhaps in fulfilment of his order, made a new picture of the town during the Prussian army's stay in Poznań in the years 1772-1773. His is a very plastic image, similar in content to the "Saxon plan", hence also prepared using the plane-table method.

The spatial interpretation of selected features of the town's relief and hydrographic network is facilitated here by descriptions of its quarters. The great plasticity of the picture derives from the use of hachuring combined with the presentation of selected environmental elements in colour. The first-plan element of this maps is the Warta valley with its islands of Ostrów Tumski, Chwaliszewo and Grobla, situated higher as a result of the accumulation of cultural layers, as well as with its 
higher terrace levels. On Grobla, as in the first view Poznan from 1618, and on Chwaliszewo two levels are marked: more and less built up. A light-blue colour is used to depict streams and water bodies (the Wierzbak and Bogdanka valleys); green, valley floors of the Warta, Bogdanka and Cybina (meadows and pastures); brown, a topographic base employing hachuring, while pink or black presents the built-up areas in the town and its suburban zone. In the graphic presentation of the river network, the nature of the channels and the steepness of banks is emphasised by a varying thickness of the bank line. In turn, hachuring alone, without a colour base, was used to depict higher-lying land: scarps, slopes, cave-ins and peaks of isolated eminences, both of natural origin and those resulting from land buildup (Ostrów Tumski, Chwaliszewo, Grobla). Very distinctly marked, mostly with hachures, are the higher terrace levels situated in the rightbank part of the Warta valley (the outskirts of Śródka, Komandoria and Zawady) as well as the residual elevations (St. Adalbert, Bald, Bachelor Hills).

In the Cybina valley, near the church of St. John of Jerusalem, an east-west oriented residual of a higher terrace level is mapped. Also presented is the bipartite structure of Ostrów Tumski: the higher-lying part adjacent to the cathedral and Zagórze, separated from the east by a fairly deep depression, a remnant of an old division of the stronghold that once existed on this island.

In turn, presented in the left-bank part of Poznan, within the so-called Groffowe Meadows, is a water body connected with the Wierzbak looking like an oxbow lake. We have got a $15^{\text {th }}$ century piece of information that located there were bodies of water called Czesnapaza and Kant. Probably the one called Czesnapaza was a remnant of a bend in the Warta extending as far as St. Adalbert's Hill, cut off in the late $14^{\text {th }}$ and early $15^{\text {th }}$ centuries (Kaniecki 1993).

The plan is supplemented with information about the state of the town's defensive system and data about a register of the property of the nobility, churches, townspeople, and Jews (Fig. 6). An additional source of information about the study area is a topographic description, Alte Topographie der Gegend von Posen, prepared in a manuscript form together with the plan. The tradition of appending descriptions to plans and maps is very old. Until the end of the $18^{\text {th }}$ century, one of their functions was to supplement the content of large-scale maps, and when small-scale maps appeared, they were used in their preparation (Jankowska 1984).

\section{Summing up}

When analysing old cartographic records from before the $19^{\text {th }}$ century in which the chief element is Poland's inland waters, it was decided that hand-drawn maps from before the period of triangulation-based field measurements were a rich source of information about the state and degree of transformation of water conditions. However, those are records varying in cartometric reliability and ways of presenting the hydrographic content, which limits their usefulness in spatial analyses. For a detailed reconstruction of water conditions in a given area, it is necessary to consider not only cartographic materials, but also historical source materials and the results of archaeological and geological research (Kaniecki 1993).

When analysing the thematic content of the plans of Poznan from the $17^{\text {th }}$ and $18^{\text {th }}$ centuries, the information concerning the town itself was found to be more reliable than that about the adjacent areas, and especially those still more distant. The changes observed over that period in the topographic and hydrographic situation of the town can be a consequence of a natural transformation of environmental elements as a result of a change in the climate, e.g. an increase in the moisture content of wetland adjacent to the town, which manifests itself in a greater number of Warta oxbow lakes, or of intentional measures taken by the town residents, e.g. a partial transformation of wetland into arable land. They can also be an effect of improved measuring methods, which influences the scope and level of detail of their graphic presentation. What limits a full interpretation of the state of the natural environment of the urban zone and the degree of its transformation is the non-homogeneity of the cartographic information as well as the diversity of ways of graphic presentation of environmental elements on the various plans and maps of the town. This 
affects the quality of the analysis conducted and the conclusions drawn, which sometimes should be treated as approximate and not fully verified.

Source maps drawn before the $19^{\text {th }}$ century present, more or less accurately, differences in the environmental conditions in the area adjacent to the town. In fact, however, none of the analysed plans of Poznań drawn between 1618 and 1784, treated separately, is reliable as to the presentation of all the earliest environmental features, as was already pointed out by $\mathrm{H}$. Münch (1937). Missing from some plans are fragments of the hydrographic network (e.g. the Warta branch called the Noteć), or major relief features, or those presented are misinterpreted (e.g. Grobla Island marked as a peninsula). Also, this is not a fully cartographic material.

The various ways of presenting meadows and pastures in the old cartographic records call for care in determining their extent and level of wetness, the more so as those land uses were the dominant landscape element of the area adjacent to Poznan at that time.

The drawing of relief on the oldest plans and views of the town, with hachures to emphasise elevations, was far from accurate. In later materials one can observe greater precision in relief mapping owing to the introduction of several standards typical of this method, e.g. the direction of hachures indicates the greatest gradient of the land surface, their thickness and density grow with the increase in slope steepness, while areas with a low gradient (up to $5^{\circ}$ ) are left unhatched, which causes 'light spots' to appear on maps where land is flat (e.g. the flat tops of the Castle Hill). On the Poznan plans under analysis, the relief and its features were also presented using a colour scale, different for each plan and map. The principle employed was that the higher the land elevation, the lighter and warmer the colour used, and vice versa. Like other methods of the graphic presentation of environmental elements employed at that time, the introduction of the colour scale was meant to make the image of the relief more plastic (Graf \& Kaniecki 2008).

A significant factor is also an assessment of the cartometric reliability of the given cartographic record, but this is quite a different matter.

\section{References}

BuczeK K., 1935. Prace kartografów pruskich w Polsce za czasów Stanisława Augusta, na tle współczesnej kartografii polskiej. Prace Komisji Atlasu Historycznego Polski 3: 115305.

GraF R. \& KANIECKI A., 2008. Sposoby przedstawiania elementów środowiskowych na XVII- i XVIII-wiecznych planach Poznania i ich wiarygodność. Przegląd Geograficzny 80(3).

Graf R., Kaniecki A. \& Medyńska-Gulij B., 2008. Dawne mapy jako źródło informacji o wodach śródlądowych i stopniu ich antropogenicznych przeobrażeń. Badania Fizjograficzne nad Polska Zachodnia, Seria A, Geografia Fizyczna 59.

JANKOWSKA M., 1984. Przydatność map topograficznych okolic Poznania z końca XVIII wieku dla badań zmian krajobrazu. Z Dziejów Kartografii 3.

JANKOWSKA M., 1993. Okoliczności i sposób opracowania pruskiej mapy topograficznej z I połowy XIX wieku w skali 1:25 000. Roczniki Akademii Rolniczej w Poznaniu: 38-45.

KACZMARCZYK K., 1924. Malarze poznańscy w XV wieku i ich cech. Kronika Miasta Poznania 2.

Kaniecki A., 1993. Poznań. Dzieje miasta woda pisane. Cz. I. Przemiany rzeźby i sieci wodnej. Wydawnictwo Aquarius, Poznań.

KANIECKI A., 2007. Atrakcyjność starych przekazów kartograficznychdlawspółczesnychbadańśrodowiskowych. In: B. Medyńska-Gulij \& L. Kaczmarek (ed.), Informacja geograficzna w kształtowaniu i ochronie środowiska przyrodniczego. Bogucki Wyd. Nauk. 11-22.

Madej J., 1987. "Polonia 1770" Karola de Perthèesa na tle osiemnastowiecznej kartografii polskiej i krajów ościennych. Biblioteka Narodowa, Warszawa.

Mika M., 1960. Ilustracje i opisy miasta Poznania z XVI-XVIII wieku. PTH, Poznań.

Münch H., 1937. Plany Poznania sprzed roku 1793 i ich wartość dla badań nad topografią miasta. Kronika Miasta Poznania R. XV, nr 1.

PAluch J., 2006. Wielkopolskie spótki wodne 1842-1918. Wągrowiec.

WAGNer M., 2002. Zmiany ksztattu sieci rzecznej na terenie Poznania $i$ okolic w świetle analizy porównawczej map z lat 1734-1890 z mapa współczesną. MS, Archiwum Zakładu Hydrologii i Gospodarki Wodnej UAM, Poznań. 